\title{
Prawno-administracyjne bariery funkcjonowania przedsiębiorstw z sektora MŚP z województwa opolskiego
}

\author{
Autorzy: Daniel Puciato, Weronika Puciato
}

\begin{abstract}
Abstrakt
Celem poznawczym artykułu jest specyfikacja głównych barier prawnych i administracyjnych, które ograniczają możliwość funkcjonowania i rozwoju mikro-, małych i średnich przedsiębiorstw. W pracy wykorzystano trzy główne metody badawcze: analizę dokumentów, metodę statystyczną oraz sondaż diagnostyczny, w ramach którego przeprowadzono wywiad pogłębiony, skategoryzowany o charakterze jawnym na właścicielach lub menedżerach 58 podmiotów z sektora MŚP z województwa opolskiego. Spośród barier prawnych i administracyjnych respondenci wskazywali na utrudnienia związane z: procedurami, instytucjami, wymiarem sprawiedliwości, systemem prawa, ochroną prawną oraz zamówieniami publicznymi. Wcześniejsze prace dotyczyły przede wszystkim barier o charakterze ekonomicznym, natomiast rzadziej analizowane były bariery prawno-administracyjne. Wyniki badań mogą być interesujące dla władz publicznych, które powinny podjąć działania zmierzające do zniwelowania barier zgłaszanych przez badanych przedsiębiorców. Przyszłe badania powinny natomiast obejmować większą liczbę podmiotów gospodarczych z całej Polski. Za szczególnie ważną należy również uznać kwestię zamówień publicznych, która będzie rozpatrywana także w kolejnych pracach autorów.
\end{abstract}

Słowa kluczowe: ekonomia instytucjonalna, przedsiębiorczość, sektor MŚP, województwo opolskie, bariery rozwoju, otoczenie prawne

\section{Wstęp}

Podmioty prowadzące działalność gospodarczą na małą skalę charakteryzują się czterema ważnymi cechami (Krupski 2005: 15-18, tobos i Puciato 2013: 109-132, Nogalski i in. 2006: 34-46, Skowronek-Mielczarek 2015:
JEL: K20, K30, M20

Historia: otrzymano 2016-01-13, poprawiono 2016-05-20, zaakceptowano 2016-05-21

46-59, Szydło 2005: 6-10, Szydło 2011: 53-75). Po pierwsze, ich działalność jest spójna z modelem rynku konkurencyjnego, co powoduje, że odgrywają niezwykle ważną rolę w procesach stymulowania przedsiębiorczości oraz innowacyjności, a w konsekwencji konkurencyjności. 
Po drugie, jako najliczniejsza grupa podmiotów gospodarczych mają znaczący udział $w$ generowaniu produktu krajowego brutto oraz tworzeniu miejsc pracy. Po trzecie, są bardzo sensytywne na warunki panujące $w$ ich otoczeniu, gdyż w następstwie takich megatrendów, jak globalizacja i internacjonalizacja, bardzo trudno jest im konkurować z wielkimi międzynarodowymi korporacjami. Po czwarte, duża liczba tego rodzaju podmiotów gospodarczych, a także swoboda ich powstawania, funkcjonowania czy likwidacja są przejawem wolności gospodarczej, będącej jednym z fundamentalnych obszarów wolności dla człowieka.

Powoduje to, że niezbędne jest prowadzenie polityki gospodarczej mającej na celu wspieranie mikro-, małych i średnich przedsiębiorstw. Polskie ustawodawstwo wskazuje nawet na konkretne obszary tego wsparcia, a mianowicie (Ustawa z dnia 2 lipca 2004 r. o swobodzie działalności gospodarczej, Dz. U. z 2015 r. poz. 584, ze zm.): (1) inicjowanie zmian stanu prawnego sprzyjających rozwojowi mikro-, małych i średnich przedsiębiorców, w tym dotyczących dostępu do środków finansowych pochodzących z kredytów i pożyczek oraz poręczeń kredytowych, (2) wspieranie instytucji umożliwiających finansowanie działalności gospodarczej na dogodnych warunkach w ramach realizowanych programów rządowych, (3) wyrównywanie warunków wykonywania działalności gospodarczej ze względu na obciążenia publicznoprawne, (4) ułatwianie dostępu do informacji, szkoleń oraz doradztwa, (5) wpieranie instytucji i organizacji działających na rzecz przedsiębiorców oraz (6) promowanie współpracy mikro-, małych i średnich przedsiębiorców z innymi przedsiębiorcami polskimi i zagranicznymi.

Mimo to w Polsce występuje obecnie wiele przeszkód utrudniających prowadzenie działalności gospodarczej na małą skalę, z których kluczowe wydają się być bariery prawne oraz administracyjne. Potwierdzają to wyniki ósmej edycji badań przeprowadzonych przez Polską Agencję Informacji i Inwestycji we współpracy z Grant Thorntonem i HSBC (Grzegorczyk 2015: 6). Według tych badań, zdaniem inwestorów, najsilniejszymi stronami Polski są: stabilność ekonomiczna, wielkość rynku wewnętrznego, dostępność materiałów i komponentów, stabilność polityczna oraz kultura organizacyjna działających na rynku firm. W opinii inwestorów najważniejszymi mankamentami są natomiast: efektywność sądownictwa gospodarczego, stałość i przewidywalność prawa, jasność i spójność przepisów prawnych, formalności związane z podatkami oraz proces uzyskiwania licencji.

Z przedstawionych badań wynika zatem, że wszystkie słabe strony Polski wymienione przez inwestorów dotyczą kwestii prawno-administracyjnych, co oznacza, że w obecnych realiach gospodarczych ten rodzaj barier prowadzenia działalności gospodarczej należy uznać za kluczowy. Mimo że cytowane wyniki badań obejmują wszystkie przedsiębiorstwa, niezależnie od ich wielkości, można wysunąć przypuszczenie, że problem ten, za sprawą niezbyt dużej siły finansowej i kompetencyjnej, dotyczy szczególnie mocno podmiotów gospodarczych z sektora MŚP.

W kontekście przedstawionych uwag wprowadzających głównym celem poznawczym artykułu jest specyfikacja głównych barier prawnych i administracyjnych, które ograniczają możliwość funkcjonowania i rozwoju mikro-, małych i średnich przedsiębiorstw. W kolejnych pracach przeprowadzona zostanie szczegółowa analiza tych barier, jak również sformułowane zostaną potencjalne sposoby ich niwelowania $w$ postaci konkretnych rekomendacji dla przedstawicieli władzy publicznej. Zakres przedmiotowy 
artykułu to zatem bariery prawno-administracyjne działalności gospodarczej prowadzonej na małą skalę, zakres podmiotowy to wybrane przedsiębiorstwa z sektora MŚP, zakres przestrzenny to województwo opolskie, zaś czasowy - pierwsza połowa 2015 roku.

Praca składa się z czterech części. W rozdziale pierwszym przedstawiono pojęcie mikro-, małych i średnich przedsiębiorstw, rozdział drugi stanowi próbę określenia znaczenia sektora MŚP dla gospodarki, w rozdziale trzecim przedstawiono metodyczne założenia pracy, natomiast rozdział czwarty zawiera charakterystykę wyników przeprowadzonych badań empirycznych.

Pojęcie mikro-, małych i średnich przedsiębiorstw

Podział przedsiębiorstw na podmioty określonej wielkości może być realizowany według kryterium ilościowego oraz jakościowego, przy czym kryterium ilościowe jest dominujące w praktyce gospodarczej i ma charakter prawno-statystyczny, natomiast kryterium jakościowe jest wykorzystywane przez naukowców i ma charakter poznawczy.

W myśl artykułów od 104 do 106 Ustawy z dnia 2 lipca 2004 r. o swobodzie działalności gospodarczej (Dz. U. z 2015 r. poz. 584, ze zm.) za mikroprzedsiębiorcę uważa się przedsiębiorcę, który w co najmniej jednym z dwóch ostatnich lat obrotowych: zatrudniał średniorocznie mniej niż 10 pracowników oraz osiągnął roczny obrót netto ze sprzedaży towarów, wyrobów i usług oraz operacji finansowych nieprzekraczający równowartości w złotych 2 milionów euro lub sumy aktywów jego bilansu sporządzonego na koniec jednego $z$ tych lat nie przekroczyły równowartości w złotych 2 milionów euro. Mały przedsiębiorca to przedsiębiorca, który w co najmniej jednym z dwóch ostatnich lat obrotowych: zatrudniał średniorocznie mniej niż 50 pracowników oraz osiągnął roczny obrót netto ze sprzedaży towarów, wyrobów i usług oraz operacji finansowych nieprzekraczający równowartości w złotych 10 milionów euro, lub sumy aktywów jego bilansu sporządzonego na koniec jednego $z$ tych lat nie przekroczyły równowartości w złotych 10 milionów euro. Za średniego przedsiębiorcę uważa się natomiast przedsiębiorcę, który w co najmniej jednym z dwóch ostatnich lat obrotowych: zatrudniał średniorocznie mniej niż 250 pracowników oraz osiągnął roczny obrót netto ze sprzedaży towarów, wyrobów i usług oraz operacji finansowych nieprzekraczający równowartości w złotych 50 milionów euro, lub sumy aktywów jego bilansu sporządzonego na koniec jednego z tych lat nie przekroczyły równowartości w złotych 43 milionów euro.

Podział przedsiębiorstw, według kryterium jakościowego, opiera się natomiast na założeniu, że istnieje pewien zestaw cech charakterystycznych wyłącznie dla małych podmiotów gospodarczych, wyraźnie odróżniających je od dużych podmiotów gospodarczych. Najważniejsze z nich to zdaniem K. Łobosa (2003: 67-78), K. Safina (2012: 53-62) i J. Targalskiego (2014: 68-76):

1. Duża samodzielność, a niekiedy wręcz dominacja przedsiębiorcy, który szczególnie na początku funkcjonowania przedsiębiorstwa pełni w nim zarówno rolę właściciela, jak i menedżera.

2. Działalność na nieodległych rynkach, głównie lokalnym i regionalnym, co implikuje dużą liczbę i bliskość kontaktów przedsiębiorcy z interesariuszami zewnętrznymi, szczególnie klientami i dostawcami.

3. Możliwość elastycznego dostosowania oferty przedsiębiorstwa do indywidualnych potrzeb i preferencji klientów.

4. Prosta struktura organizacyjna, często typu organicznego, cechująca się niskim stopniem 
zbiurokratyzowania oraz brakiem formalnych procedur i norm organizacyjnych.

5. Niesformalizowany charakter kontaktów między kierownictwem a pracownikami, które zazwyczaj są wielostronne, częste i bezpośrednie.

6. Wysoka reaktywność i duża elastyczność oraz wynikająca z nich możliwość szybkiej reakcji na zmiany warunków otoczenia.

7. Zasoby właściciela i jego rodziny to główna baza finansowa tego rodzaju przedsiębiorstw, co z jednej strony daje dużą swobodę działania, z drugiej natomiast wywołuje konieczność wyboru niskokapitałowej ścieżki rozwoju.

8. Niewielki udział w rynku.

9. Zdecydowana przewaga decyzji o charakterze operacyjnym, w porównaniu do strategicznych.

10. Mały stopień dywersyfikacji, przejawiający się zwykle wytwarzaniem jednego produktu.

\section{Znaczenie sektora MŚP dla gospodarki narodowej}

Działalność gospodarcza prowadzona na małą skalę odgrywa znaczącą rolę w gospodarkach krajów rozwiniętych. Mikro-, małe i średnie przedsiębiorstwa wypełniają nisze rynkowe, którymi z jakiś powodów nie są lub nie mogą być zainteresowane duże podmioty gospodarcze. Obie grupy przedsiębiorstw są zatem względem siebie komplementarne, a przedstawiane przez nie oferty lepiej zaspokajają potrzeby indywidualne i zbiorowe zgłaszane przez konsumentów. Ich elastyczność oraz szybkość reakcji na bodźce $z$ otoczenia powodują, że $w$ tego rodzaju podmiotach generowanych jest wiele innowacji, co również nie jest bez znaczenia $w$ kontekście stopnia zaspokajania tychże potrzeb. Duża liczba mikro-, małych i średnich przedsiębiorstw powoduje także, że odgrywają one znaczącą rolę w procesie tworzenia wartości dodanej oraz miejsc pracy.

Z raportu Polskiej Agencji Rozwoju Przedsiębiorczości wynika, że sektor przedsiębiorstw generuje około $73 \%$ polskiego PKB, a same podmioty z sektora MŚP około $48,5 \%$ tej wartości. W latach 2004-2012 udział ten kształtował się na podobnym poziomie, przy czym nieznacznie zmniejszył się w przypadku mikroprzedsiębiorstw, zaś zwiększył w odniesieniu do małych i średnich przedsiębiorstw (tabela 1). Eurostat, używając nieco innej metodologii badawczej, oszacował natomiast udział sektora przedsiębiorstw w tworzeniu polskiego produktu krajowego na około $44 \%$. Ponad połowe $(50,9 \%)$ tej wartości generowały podmioty z sektora MŚP, w tym: mikroprzedsiębiorstwa $16,5 \%$, małe firmy 13,5\%, natomiast średnie 20,9\% (Raport 2015: 16).

W przypadku polskiego rynku pracy na około $14,2 \mathrm{mln}$ pracujących blisko $8,9 \mathrm{mln}$ osób jest zatrudnionych w sektorze przedsiębiorstw. Niemal $38 \% \mathrm{z}$ nich pracuje $\mathrm{w}$ mikroprzedsiębiorstwach, około $13,5 \% \mathrm{w}$ małych podmiotach gospodarczych, zaś blisko $18 \%$ w średnich firmach. W sumie odsetek pracujących w sektorze MŚP wynosi zatem około $69,5 \%$. W latach 2004-2013 udział pracujących w mikroprzedsiębiorstwach nieznacznie się zmniejszył, w małych firmach nieznacznie się zwiększył, natomiast $w$ średnich podmiotach gospodarczych pozostał na podobnym poziomie (tabela 2 ). W przypadku rynku pracy oprócz aspektów ilościowych istotne są także kwestie strukturalne. Popyt na prace zgłaszany ze strony podmiotów small biznesu dotyczy często stanowisk o niezbyt wysokich wymaganiach odnośnie kwalifikacji zawodowych, co daje szanse na zatrudnienie także osób gorzej wykształconych. Ponadto, małe przedsiębiorstwa, w przeciwieństwie do dużych 
Tabela 1. Struktura PKB w Polsce w latach 2004-2012

\begin{tabular}{|c|c|c|c|c|c|c|c|c|c|}
\hline \multirow{3}{*}{ Rok } & \multirow{3}{*}{$\begin{array}{l}\text { PKB (mln } \\
\text { PLN) }\end{array}$} & \multicolumn{6}{|c|}{$\begin{array}{l}\text { Wartość dodana brutto wytworzo- } \\
\text { na przez przedsiębiorstwa }\end{array}$} & \multirow{3}{*}{$\begin{array}{c}\text { Wartość } \\
\text { dodana } \\
\text { brutto } \\
\text { innych } \\
\text { podmio- }\end{array}$} & \multirow{3}{*}{$\begin{array}{l}\text { Cla i po- } \\
\text { datki }\end{array}$} \\
\hline & & \multirow{2}{*}{$\begin{array}{l}\text { Ogó- } \\
\text { łem }\end{array}$} & \multicolumn{4}{|c|}{ MMŚP } & \multirow{2}{*}{ Duże } & & \\
\hline & & & Razem & Mikro- & Małe & Średnie & & & \\
\hline 2004 & 923248 & $70,5 \%$ & $48,6 \%$ & $31,0 \%$ & $7,6 \%$ & $10,0 \%$ & $21,9 \%$ & $18,3 \%$ & $11,1 \%$ \\
\hline 2005 & 983302 & $70,3 \%$ & $47,8 \%$ & $31,5 \%$ & $7,4 \%$ & $8,9 \%$ & $22,5 \%$ & $17,8 \%$ & $11,9 \%$ \\
\hline 2006 & $\begin{array}{c}1060 \\
031\end{array}$ & $70,7 \%$ & $47,8 \%$ & $31,0 \%$ & $7,4 \%$ & $9,3 \%$ & $22,9 \%$ & $17,2 \%$ & $12,2 \%$ \\
\hline 2007 & $\begin{array}{c}1176 \\
737\end{array}$ & $70,8 \%$ & $47,3 \%$ & $30,4 \%$ & $7,2 \%$ & $9,8 \%$ & $23,5 \%$ & $16,7 \%$ & $12,5 \%$ \\
\hline 2008 & $\begin{array}{c}1275 \\
432\end{array}$ & $71,1 \%$ & $47,2 \%$ & $29,9 \%$ & $7,4 \%$ & $9,9 \%$ & $23,9 \%$ & $16,5 \%$ & $12,5 \%$ \\
\hline 2009 & $\begin{array}{c}1343 \\
366\end{array}$ & $72,3 \%$ & $48,4 \%$ & $30,4 \%$ & $7,9 \%$ & $10,1 \%$ & $23,9 \%$ & $16,5 \%$ & $11,1 \%$ \\
\hline 2010 & $\begin{array}{c}1416 \\
447\end{array}$ & $71,6 \%$ & $47,6 \%$ & $29,6 \%$ & $7,7 \%$ & $10,4 \%$ & $24,0 \%$ & $16,5 \%$ & $11,9 \%$ \\
\hline 2011 & $\begin{array}{c}1528 \\
127\end{array}$ & $71,8 \%$ & $47,3 \%$ & $29,4 \%$ & $7,8 \%$ & $10,1 \%$ & $24,5 \%$ & $16,1 \%$ & $12,2 \%$ \\
\hline 2012 & $\begin{array}{c}1596 \\
378\end{array}$ & $73,0 \%$ & $48,5 \%$ & $29,7 \%$ & $7,8 \%$ & $11,0 \%$ & $24,5 \%$ & $15,6 \%$ & $11,4 \%$ \\
\hline
\end{tabular}

Źródło: (Raport 2015).

Tabela 2. Struktura liczby pracujących w sektorze przedsiębiorstw w Polsce w latach 2004-2013

\begin{tabular}{|c|c|c|c|c|}
\hline \multirow{2}{*}{ Rok } & \multicolumn{4}{|c|}{ Wielkość przedsiębiorstwa } \\
\cline { 2 - 5 } & Mikro- & Małe & Średnie & Duże \\
\hline 2004 & $41,46 \%$ & $11,85 \%$ & $17,91 \%$ & $28,78 \%$ \\
\hline 2005 & $41,06 \%$ & $11,73 \%$ & $18,03 \%$ & $29,18 \%$ \\
\hline 2006 & $40,61 \%$ & $11,41 \%$ & $18,03 \%$ & $29,95 \%$ \\
\hline 2007 & $40,06 \%$ & $11,23 \%$ & $18,05 \%$ & $30,66 \%$ \\
\hline 2008 & $39,26 \%$ & $12,59 \%$ & $17,98 \%$ & $30,27 \%$ \\
\hline 2009 & $39,23 \%$ & $12,72 \%$ & $18,61 \%$ & $29,43 \%$ \\
\hline 2010 & $38,37 \%$ & $13,91 \%$ & $18,61 \%$ & $30,11 \%$ \\
\hline 2011 & $38,86 \%$ & $13,09 \%$ & $18,24 \%$ & $29,82 \%$ \\
\hline 2012 & $38,71 \%$ & $13,47 \%$ & $17,93 \%$ & $29,89 \%$ \\
\hline 2013 & $37,89 \%$ & $13,69 \%$ & $17,89 \%$ & $30,53 \%$ \\
\hline
\end{tabular}

Źródło: opracowanie własne na podstawie (Raport 2015: 18). 
podmiotów gospodarczych, zlokalizowane są w niemal każdej, nawet najmniejszej miejscowości, co powoduje bardziej równomierną przestrzennie alokację zasobów ludzkich i umożliwia podjęcie pracy na miejscu, bez konieczności dojazdu do dużych aglomeracji. W polskich warunkach infrastrukturalnych oraz kulturowych jest to bowiem czynnik, z powodu którego część ludzi zniechęca się do aktywności zawodowej, z wszystkimi negatywnymi skutkami tego zjawiska, zarówno dla zasobów pracy, jak i gospodarek lokalnych, regionalnych i narodowej.

Według Głównego Urzędu Statystycznego w roku 2014 w województwie opolskim funkcjonowało $100 \quad 077$ podmiotów gospodarczych wpisanych do systemu REGON, z czego najliczniejszą grupę $(95,79 \%)$ stanowiły mikroprzedsiębiorstwa. Małych przedsiębiorstw było 3,45\%, średnich $0,68 \%$, natomiast dużych zaledwie 0,09\%. Oznacza to że $99,91 \%$ podmiotów gospodarczych zarejestrowanych na obszarze Opolszczyzny to podmioty zaliczane do sektora MŚP. Strukturę podmiotów gospodarczych w oparciu o kryterium wielkości także dla innych polskich województw przedstawiono w tabeli 3.

Ze względu na niewielki rozmiar województwa opolskiego, na jego obszarze znajdowała się najmniejsza, oprócz Podlasia, liczba podmiotów gospodarczych. Mikroprzedsiębiorstwa, których działalność gospodarcza została zarejestrowana na obszarze Opolszczyzny, stanowiły zaledwie 2,43\% wszystkich

Tabela 3. Podmioty gospodarcze wpisane do systemu REGON według wielkości w roku 2014

\begin{tabular}{|c|c|c|c|c|c|c|c|c|c|c|}
\hline \multirow{3}{*}{ Województwo } & \multicolumn{10}{|c|}{ Wielkość przedsiębiorstwa } \\
\hline & \multicolumn{2}{|c|}{ Mikro- } & \multicolumn{2}{|c|}{ Małe } & \multicolumn{2}{|c|}{ Średnie } & \multicolumn{2}{|c|}{ Duże } & \multicolumn{2}{|c|}{ Razem } \\
\hline & liczba & $\%$ & liczba & $\%$ & liczba & $\%$ & liczba & $\%$ & liczba & $\%$ \\
\hline Dolnośląskie & 338255 & 96,34 & 10369 & 2,95 & 2141 & 0,61 & 356 & 0,10 & 351121 & 100,00 \\
\hline $\begin{array}{l}\text { Kujawsko- } \\
\text {-pomorskie }\end{array}$ & 183312 & 95,44 & 6964 & 3,63 & 1584 & 0,82 & 218 & 0,11 & 192078 & 100,00 \\
\hline Lubelskie & 164510 & 95,86 & 5713 & 3,33 & 1253 & 0,73 & 144 & 0,08 & 171620 & 100,00 \\
\hline Lubuskie & 105404 & 95,75 & 3850 & 3,50 & 740 & 0,67 & 90 & 0,08 & 110084 & 100,00 \\
\hline Łódzkie & 227875 & 95,12 & 9623 & 4,02 & 1822 & 0,76 & 258 & 0,11 & 239578 & 100,00 \\
\hline Małopolskie & 340861 & 95,54 & 13163 & 3,69 & 2419 & 0,68 & 342 & 0,10 & 356785 & 100,00 \\
\hline Mazowieckie & 710823 & 95,78 & 25203 & 3,40 & 5069 & 0,68 & 1077 & 0,15 & 742172 & 100,00 \\
\hline Opolskie & 95865 & 95,79 & 3450 & 3,45 & 676 & 0,68 & 86 & 0,09 & 100077 & 100,00 \\
\hline Podkarpackie & 155180 & 95,46 & 5912 & 3,64 & 1272 & 0,78 & 192 & 0,12 & 162556 & 100,00 \\
\hline Podlaskie & 94465 & 96,06 & 3043 & 3,09 & 735 & 0,75 & 96 & 0,10 & 98339 & 100,00 \\
\hline Pomorskie & 264455 & 95,82 & 9348 & 3,39 & 1945 & 0,70 & 242 & 0,09 & 275990 & 100,00 \\
\hline Śląskie & 438364 & 94,90 & 19291 & 4,18 & 3708 & 0,80 & 570 & 0,12 & 461933 & 100,00 \\
\hline $\begin{array}{l}\text { Święto- } \\
\text { krzyskie }\end{array}$ & 105140 & 95,47 & 4020 & 3,65 & 850 & 0,77 & 120 & 0,11 & 110130 & 100,00 \\
\hline $\begin{array}{l}\text { Warmińsko- } \\
\text {-mazurskie }\end{array}$ & 117706 & 95,42 & 4531 & 3,67 & 1009 & 0,82 & 115 & 0,09 & 123361 & 100,00 \\
\hline Wielkopolskie & 385072 & 95,22 & 15823 & 3,91 & 3089 & 0,76 & 435 & 0,11 & 404419 & 100,00 \\
\hline $\begin{array}{l}\text { Zachodnio- } \\
\text { pomorskie }\end{array}$ & 211345 & 96,33 & 6623 & 3,02 & 1298 & 0,59 & 140 & 0,06 & 219406 & 100,00 \\
\hline
\end{tabular}


firm tej wielkości w Polsce. W przypadku małych przedsiębiorstw udział ten wynosi $2,35 \%$, średnich podmiotów gospodarczych - 2,28\%, natomiast dużych przedsiębiorstw 1,92\%. Świadczy to o niewielkiej nadreprezentacji sektora mikro-, małych i średnich przedsiębiorstw w przedsiębiorstwach ogółem na obszarze województwa opolskiego w porównaniu do pozostałych polskich regionów. Dokumentuje to, zdaniem autora, znaczącą rolę sektora MŚP dla gospodarki regionalnej Opolszczyzny (tabela 4).

\section{Metodyczne założenia badań}

W pracy wykorzystano trzy główne metody badawcze: analizę dokumentów, analizy statystyczne oraz sondaż diagnostyczny. W ramach pierwszej przeprowadzono analizę piśmiennictwa oraz opracowań Polskiej Agencji Rozwoju Przedsiębiorczości i Głównego Urzędu Statystycznego. Dane ze źródeł wtórnych poddano następnie analizie statystycznej, dokonując oceny struktury. W ramach metody sondażu diagnostycznego

Tabela 4. Podmioty gospodarcze wpisane do systemu REGON według województw w roku 2014

\begin{tabular}{|c|c|c|c|c|c|c|c|c|}
\hline \multirow{3}{*}{$\begin{array}{c}\text { Woje- } \\
\text { wództwo }\end{array}$} & \multicolumn{8}{|c|}{ Wielkość przedsiębiorstwa } \\
\hline & \multicolumn{2}{|c|}{ Mikro- } & \multicolumn{2}{|c|}{ Małe } & \multicolumn{2}{|c|}{ Średnie } & \multicolumn{2}{|c|}{ Duże } \\
\hline & liczba & $\%$ & liczba & $\%$ & liczba & $\%$ & liczba & $\%$ \\
\hline Dolnośląskie & 338255 & 8,59 & 10369 & 7,06 & 2141 & 7,23 & 356 & 7,94 \\
\hline $\begin{array}{l}\text { Kujawsko- } \\
\text {-pomorskie }\end{array}$ & 183312 & 4,65 & 6964 & 4,74 & 1584 & 5,35 & 218 & 4,86 \\
\hline Lubelskie & 164510 & 4,18 & 5713 & 3,89 & 1253 & 4,23 & 144 & 3,21 \\
\hline Lubuskie & 105404 & 2,68 & 3850 & 2,62 & 740 & 2,50 & 90 & 2,01 \\
\hline Łódzkie & 227875 & 5,79 & 9623 & 6,55 & 1822 & 6,15 & 258 & 5,76 \\
\hline Małopolskie & 340861 & 8,65 & 13163 & 8,96 & 2419 & 8,17 & 342 & 7,63 \\
\hline Mazowieckie & 710823 & 18,05 & 25203 & 17,15 & 5069 & 17,12 & 1077 & 24,03 \\
\hline Opolskie & 95865 & 2,43 & 3450 & 2,35 & 676 & 2,28 & 86 & 1,92 \\
\hline Podkarpackie & 155180 & 3,94 & 5912 & 4,02 & 1272 & 4,30 & 192 & 4,28 \\
\hline Podlaskie & 94465 & 2,40 & 3043 & 2,07 & 735 & 2,48 & 96 & 2,14 \\
\hline Pomorskie & 264455 & 6,71 & 9348 & 6,36 & 1945 & 6,57 & 242 & 5,40 \\
\hline Śląskie & 438364 & 11,13 & 19291 & 13,13 & 3708 & 12,52 & 570 & 12,72 \\
\hline $\begin{array}{l}\text { Święto- } \\
\text { krzyskie }\end{array}$ & 105140 & 2,67 & 4020 & 2,74 & 850 & 2,87 & 120 & 2,68 \\
\hline $\begin{array}{l}\text { Warmińsko- } \\
\text {-mazurskie }\end{array}$ & 117706 & 2,99 & 4531 & 3,08 & 1009 & 3,41 & 115 & 2,57 \\
\hline Wielkopolskie & 385072 & 9,78 & 15823 & 10,77 & 3089 & 10,43 & 435 & 9,71 \\
\hline $\begin{array}{l}\text { Zachodnio- } \\
\text { pomorskie }\end{array}$ & 211345 & 5,37 & 6623 & 4,51 & 1298 & 4,38 & 140 & 3,12 \\
\hline Razem & 3938632 & 100,00 & 146926 & 100,00 & 29610 & 100,00 & 4481 & 100,00 \\
\hline
\end{tabular}

Źródło: opracowanie własne na podstawie danych z GUS. 
przeprowadzono wywiad pogłębiony, skategoryzowany o charakterze jawnym, dotyczący głównych barier rozwoju mikro-, małych i średnich przedsiębiorstw. Wywiad przeprowadzono na właścicielach lub menedżerach 58 podmiotów gospodarczych z sektora MŚP zlokalizowanych w województwie opolskim, w okresie od marca do czerwca 2015 roku. Największą grupę rozpatrywanych podmiotów (41,38\%) stanowiły mikroprzedsiębiorstwa, małych przedsiębiorstw było $31,03 \%$, natomiast średnich $27,59 \%$. W analizowanej próbce znajdowały się podmioty gospodarcze zlokalizowane w każdym z jedenastu powiatów województwa opolskiego, najwięcej z Opola - 17,24\% oraz z powiatów: kędzierzyńsko-kozielskiego oraz nyskiego - po $12,07 \%$. Większość analizowanych firm $(60,34 \%)$ zorganizowana była $w$ formie przedsiębiorstwa własności indywidualnej, natomiast spółek, głównie cywilnych, jawnych i partnerskich, było 39,66\%. Badane przedsiębiorstwa prowadziły działalność gospodarczą charakterystyczną dla siedmiu sekcji PKD. Najliczniejsze były podmioty zajmujące się: handlem detalicznym i hurtowym oraz naprawą samochodów $(18,97 \%)$, a także przetwórstwem przemysłowym $(17,24 \%)$. Pozostałe przedsiębiorstwa prowadziły działalność gospodarczą związaną z: budownictwem $(15,52 \%)$, zakwaterowaniem i usługami gastronomicznymi $(13,79 \%)$, transportem i gospodarką magazynową (12,07\%), usługami administrowania i działalnością wspierającą $(12,07 \%)$ oraz działalnością profesjonalną, naukową i techniczną (10,34\%). Zasięg rynku co trzeciego analizowanego przedsiębiorstwa miał charakter regionalny, co czwartego lokalny lub krajowy, natomiast co szóstego - międzynarodowy. Najliczniejsza grupa rozpatrywanych podmiotów - 22,41\% - funkcjonowała na rynku od jednego do dwóch lat, po 17,24\% od dwóch do trzech lub powyżej pięciu lat, $15,52 \%$ od czterech do pięciu lat, natomiast po $13,79 \%$ z nich poniżej roku lub od czterech do pięciu lat (tabela 5).

\section{Główne bariery \\ prawne i administracyjne funkcjonowania podmiotów gospodarczych na Opolszczyźnie w świetle badań sondażowych}

Badani właściciele lub menedżerowie podmiotów zaliczanych do sektora mikro-, małych i średnich przedsiębiorstw, którzy zostali poproszeni o wymienienie najważniejszych barier prowadzonej przez nich działalności gospodarczej, wskazali na przeszkody ekonomiczne oraz prawno-administracyjne. Wśród barier ekonomicznych wymieniali zwykle: zbyt wysokie ich zdaniem obciążenia podatkowe oraz „parapodatkowe” (składki na FUS oraz NFZ), utrudniony dostęp do zewnętrznych źródeł finansowania (głównie kredytów bankowych) oraz brak spójnej i skutecznej polityki gospodarczej wspierającej małe przedsiębiorstwa.

Spośród barier prawnych i administracyjnych, które są głównym przedmiotem badań w pracy, respondenci wskazywali na utrudnienia, które w uproszczeniu można podzielić na następujące grupy: procedury, instytucje (w sensie podmiotowym), wymiar sprawiedliwości, system prawa, ochrona prawna oraz zamówienia publiczne. Wśród barier związanymi z szeroko pojętymi procedurami badani wskazywali na dużą liczbę utrudnień biurokratycznych i wysoki stopień formalizacji, z którymi muszą się borykać podczas prowadzenia przedsiębiorstwa. Część z nich napotkali już na etapie zakładania działalności gospodarczej, chociażby w postaci: wciąż jeszcze stosunkowo długiego czasu potrzebnego do rejestracji przedsiębiorstwa czy skomplikowanego trybu uzyskiwania zezwoleń, koncesji czy licencji. 
Tabela 5. Klasyfikacja analizowanych przedsiębiorstw w oparciu o wybrane kryteria

\begin{tabular}{|c|c|c|}
\hline Wyszczególnienie & $\begin{array}{l}\text { Liczba badanych } \\
\text { podmiotów }\end{array}$ & $\begin{array}{l}\text { Odsetek badanych } \\
\text { podmiotów [\%] }\end{array}$ \\
\hline Wielkość & $x$ & $x$ \\
\hline Mikro & 24 & 41,38 \\
\hline Małe & 18 & 31,03 \\
\hline Średnie & 16 & 27,59 \\
\hline Razem: & 58 & 100,00 \\
\hline Lokalizacja ogólna (powiat) & $x$ & $\times$ \\
\hline Brzeski & 5 & 8,62 \\
\hline Głubczycki & 4 & 6,90 \\
\hline Kędzierzyńsko-kozielski & 7 & 12,07 \\
\hline Krapkowicki & 3 & 5,17 \\
\hline Kluczborski & 4 & 6,90 \\
\hline Namysłowski & 4 & 6,90 \\
\hline Nyski & 7 & 12,07 \\
\hline Oleski & 4 & 6,90 \\
\hline Opole & 10 & 17,24 \\
\hline Opolski & 3 & 5,17 \\
\hline Prudnicki & 4 & 6,90 \\
\hline Strzelecki & 3 & 5,17 \\
\hline Razem: & 58 & 100,00 \\
\hline Forma prawno-organizacyjna & $x$ & $x$ \\
\hline Przedsiębiorstwo własności indywidualnej & 35 & 60,34 \\
\hline Spółka & 23 & 39,66 \\
\hline Razem: & 58 & 100,00 \\
\hline Rodzaj działalności gospodarczej według PKD & $\times$ & $x$ \\
\hline Przetwórstwo przemysłowe & 10 & 17,24 \\
\hline Budownictwo & 9 & 15,52 \\
\hline Handel hurtowy i detaliczny, naprawa pojazdów samochodowych & 11 & 18,97 \\
\hline Transport i gospodarka magazynowa & 7 & 12,07 \\
\hline $\begin{array}{c}\text { Działalność związana z zakwaterowa- } \\
\text { niem i usługami gastronomicznymi }\end{array}$ & 8 & 13,79 \\
\hline Działalność profesjonalna, naukowa i techniczna & 6 & 10,34 \\
\hline $\begin{array}{l}\text { Działalność w zakresie usług administro- } \\
\text { wania i działalność wspierająca }\end{array}$ & 7 & 12,07 \\
\hline Razem: & 58 & 100,00 \\
\hline Zasięg rynku & $x$ & $x$ \\
\hline Lokalny & 16 & 27,59 \\
\hline Regionalny & 20 & 34,48 \\
\hline Krajowy & 15 & 25,86 \\
\hline Międzynarodowy & 7 & 12,07 \\
\hline Razem: & 58 & 100,00 \\
\hline Okres funkcjonowania na rynku [lata] & $x$ & $x$ \\
\hline$<1$ & 8 & 13,79 \\
\hline$<1-2)$ & 13 & 22,41 \\
\hline$<2-3)$ & 10 & 17,24 \\
\hline$<3-4)$ & 8 & 13,79 \\
\hline$<4-5)$ & 9 & 15,52 \\
\hline$\geq 5$ & 10 & 17,24 \\
\hline Razem: & 58 & 100,00 \\
\hline
\end{tabular}

Źródło: opracowanie własne na podstawie badań sondażowych. 
W trakcie prowadzenia działalności gospodarczej respondenci zobowiązani byli do wypełniania i składania bardzo dużej liczby różnego rodzaju formularzy oraz poddawani byli częstym i kłopotliwym kontrolom. Mocno ograniczało to czas, jaki mogli poświęcić na zarządzanie swoimi firmami. Ważną zdaniem przedsiębiorców barierą utrudniającą funkcjonowanie małego przedsiębiorstwa jest ponadto skomplikowana i długotrwała procedura otrzymywania interpretacji podatkowej od organów skarbowych. Sytuację komplikuje jeszcze to, że obecnie w imieniu Ministra Finansów wydają je dyrektorzy tylko pięciu izb skarbowych usytuowanych w Bydgoszczy, Katowicach, Łodzi, Poznaniu oraz Warszawie. Zdaniem badanych jeszcze bardziej utrudnia to dostęp do tak dla nich ważnych usług publicznych. Ponadto procedura uzyskiwania interpretacji jest bardzo sformalizowana, podatnik nie tylko musi opisać stan faktyczny, jakiego ma dotyczyć interpretacja, ale również przedstawić swój pogląd. Oznacza to, że nie wystarczy poprzestać na zadaniu pytania organowi. Jeżeli wniosek jest niepełny bądź nieprecyzyjny w ocenie organu, wzywa on podatnika o jego uzupełnienie, wyznaczając krótki termin na odpowiedź, zastrzegając, że brak odpowie$\mathrm{dzi}$ będzie skutkował pozostawieniem wniosku bez rozpoznania. Jeżeli podatnik nie zgadza się z interpretacją - nim złoży skargę do wojewódzkiego sadu administracyjnego - musi przejść dodatkowy etap, jakim jest wezwanie organu do usunięcia naruszenia prawa, co jeszcze bardziej wydłuża tę procedurę. Główną barierą utrudniającą rozwój badanych przedsiębiorstw okazał się natomiast skomplikowany tryb aplikowania o środki finansowe z Unii Europejskiej. Respondenci wskazywali tutaj przede wszystkim na nadmierną formalizację, zbyt późne pojawianie się informacji dotyczących szczegółów ogłaszanych konkursów oraz niejasny, specyficzny dla unijnej nomenklatury język ich opisu.

Głównymi barierami związanymi z funkcjonowaniem instytucji publicznych, które świadczą usługi dla przedsiębiorców, były zdaniem respondentów: ograniczone kompetencje urzędników, szczególnie w urzędach zlokalizowanych w mniejszych miejscowościach, wciąż jeszcze nie zawsze życzliwe podejście do petenta oraz długi czas rozpoznawania spraw administracyjnych i podatkowych. Należy przy tym zaznaczyć, że na gruncie prawa administracyjnego i podatkowego sprawa winna zostać załatwiona niezwłocznie, a jeżeli wymagane jest przeprowadzenie postępowania dowodowego - w okresie miesiąca. W szczególnie skomplikowanych sprawach termin można przedłużyć do dwóch miesięcy. Jednak w praktyce urzędniczej termin dwumiesięczny jest uznawany za normę, niezależnie od typu sprawy. Ankietowani przedsiębiorcy wskazywali także na dużą opresyjność urzędów oraz nieprzyjazne godziny przyjmowania petentów. Aktualnie wprawdzie funkcjonuje wymóg, aby co najmniej raz w tygodniu urząd był czynny w godzinach popołudniowych, np. do godziny 1700 czy 1800, lecz urzędy w mniejszych miejscowościach nie zawsze przestrzegają tego wymogu, a nawet jeżeli się na to decydują, to ograniczają się do minimum, a więc do jednego dnia w tygodniu. Ponieważ nie ma reguły, jaki to musi być dzień, zaobserwować tu można również dużą dowolność, która często powoduje chaos i dezorientację przedsiębiorcy. Za sprawą niezbyt dobrze rozwiniętej jeszcze w Polsce e-administracji, opisane kwestie mocno utrudniają funkcjonowanie mikro-, małych i średnich przedsiębiorstw.

Za najważniejszą przeszkodę związaną $z$ funkcjonowaniem samego wymiaru sprawiedliwości respondenci z Opolszczyzny uznali natomiast przewlekłość postępowań sądowych w sprawach 
gospodarczych, cywilnych i rejestrowych. Wymieniano także ograniczone możliwości alternatywnych sposobów rozwiązywania sporów, takich jak: mediacje czy arbitraż. Ważnym obszarem tych problemów było dochodzenie swoich należności, co dodatkowo wiąże się z przewlekłością postępowań komorniczych. W sytuacji, w której część spraw jest celowo przeciągana przez pełnomocników dłużnika, dochodzi często do ukrycia majątku i braku możliwości odzyskania długu przez wierzyciela.

Dla sporej grupy przedstawicieli sektora MŚP poważnym problemem jest także sam system prawa, a w szczególności takie kwestie jak: niestabilność i niezrozumiałość przepisów oraz niska jakość i konieczność szybkiej nowelizacji nowo powstałych aktów prawnych. Za jedną z przyczyn takiego stanu rzeczy badani uznali zbyt krótki czas przeznaczany na konsultacje społeczne, dotyczące nowych rozwiązań prawnych, co w praktyce oznacza ich pozorność z wszystkimi jej negatywnymi następstwami. Ponadto polskie prawo nie nakazuje już również obowiązkowego uwzględnienia wyników tych konsultacji. Respondenci wskazali także na najczęstsze obszary występowania tego rodzaju problemów, do których zaliczyli: podatki, politykę przestrzenną, regulacje rynków oraz partnerstwo publiczno-prywatne.

Dla przeciętnego przedsiębiorcy prowadzącego działalność na małą skalę wciąż jeszcze ograniczona jest dostępność do ochrony prawnej. Spowodowane jest to głównie relatywnie wysokimi kosztami obsługi prawnej oraz nie otrzymywaniem zwrotu tego rodzaju kosztów w przypadku wygrania procesu sądowego: cywilnego lub gospodarczego. Jeżeli od wyroku sądu pierwszej instancji wniesiona zostanie apelacja, przedsiębiorca musi ponosić te koszty dwukrotnie, co jest częstym przedmiotem ich obaw, szczególnie w kontekście podwojenia stawek minimalnych opłat za czynności radców prawnych i adwokatów, które weszły w życie 1 stycznia tego roku.

Niezwykle ważną grupą barier dla ankietowanych właścicieli lub menedżerów małych przedsiębiorstw okazało się również funkcjonowanie polskiego systemu zamówień publicznych. Badani wskazywali na trzy momenty krytyczne w tym obszarze, do których zaliczali: składanie ofert, rozstrzygnięcie konkursu oraz wypłatę środków finansowych. W pierwszym przypadku respondenci nisko ocenili jakość specyfikacji stanowiących podstawę przygotowywanych ofert. Ich zdaniem wciąż przesądzającym i praktycznie jedynym kryterium wyboru oferenta jest cena. Ogranicza to możliwość konkurowania tak ważnymi z perspektywy szans rozwoju samych przedsiębiorstw oraz całej gospodarki narodowej atrybutami, jak: innowacyjność, jakość czy koszty eksploatacji. Przy tak silnej formalizacji działań i niestosowaniu dobrych praktyk w obszarze zamówień publicznych, podobnie jak ma to miejsce w innych krajach, większość ryzyk związanych z realizacją przedsięwzięć przerzucana jest na wykonawców. Drugim zdaniem przedsiębiorców obszarem krytycznym związanym z zamówieniami publicznymi są bardzo wysokie koszty oraz krótki czas realizacji czynności odwoławczych. Mocno to utrudnia korzystanie z tego bardzo ważnego z punktu widzenia wolności gospodarczej uprawnienia. Trzecią istotną barierą w tym obszarze jest powszechne uzależnianie wypłaty środków finansowych przez zamawiającego od faktu otrzymania dofinansowania od podmiotu trzeciego, np. Narodowego Funduszu Ochrony Środowiska i Gospodarki Wodnej lub działających w jego imieniu funduszy wojewódzkich i banków oraz instytucji zarządzających środkami finansowymi pochodzącymi z funduszy Unii Europejskiej lub działających w ich 
imieniu podmiotów pośredniczących oraz wdrażających.

\section{Podsumowanie}

Jak wykazano w poprzednim rozdziale artykułu, w polskiej rzeczywistości gospodarczej wciąż występuje wiele prawno-administracyjnym barier utrudniających uruchamianie, prowadzenie i rozwijanie mikro-, małych i średnich przedsiębiorstw. Choć zakres przestrzenny badań uprawnia do tego rodzaju stwierdzeń wyłącznie w odniesieniu do podmiotów gospodarczych z województwa opolskiego, to biorąc pod uwagę również wyniki innych opracowań na ten temat, można z pewną ostrożnością spostrzeżenie to aproksymować także na podmioty z pozostałych polskich regionów.

Dalszy, dynamiczny rozwój podmiotów sektora MŚP i wynikające z niego korzyści mezo- i makrogospodarcze, nie będą możliwe bez odpowiednio zaprogramowanej i zrealizowanej polityki gospodarczej, ukierunkowanej na wsparcie tego rodzaju przedsiębiorstw. Jednym z pożądanych kierunków tych działań powinny być rozwiązania zmierzające do usunięcia odnotowanych

\section{Bibliografia}

Grzegorczyk M. (2015), Super, taki mamy klimat, „Puls Biznesu”, 4-6 grudnia, s. 6.

Krupski R. (2005), Planowany czy nie planowany rozwój małych firm. Co z teorią zarządzania strategicznego, „Przegląd Organizacji”, nr 3, s. 15-18.

Łobos K. (2003), Teoria struktur organizacyjnych. Stan i perspektywy, Wrocław, Wydawnictwo Akademii Ekonomicznej im. Oscara Langego we Wrocławiu. w badaniach przeszkód, a w konsekwencji do kształtowania przyjaznego dla polskich przedsiębiorców otoczenia prawno-administracyjnego.

$\mathrm{Na}$ gruncie poznawczym natomiast w pracy potwierdzono coraz silniejsze związki zachodzące między naukami ekonomicznymi a prawnymi, przejawiającymi się chociażby w rozwoju takich nurtów, jak ekonomia instytucjonalna czy ekonomiczna analiza prawa. W odniesieniu do praktyki gospodarczej nie sposób również dzisiaj zarządzać jakimkolwiek podmiotem gospodarczym, bez chociażby elementarnej znajomości przepisów prawa, co powinno znaleźć swoje odzwierciedlenie w programach nauczania uczelni ekonomicznych.

Wyniki przeprowadzonych badań potwierdziły również znaczącą rolę systemu zamówień publicznych dla funkcjonowania współczesnych polskich przedsiębiorstw. Problematyka ta będzie rozważana w kolejnych pracach, również w kontekście silnie związanych z zamówieniami publicznymi zjawiskami ekonomicznymi, takimi jak: asymetria informacji, pokusa nadużycia, negatywna selekcja, defekt koordynacji czy teoria agencji.

Łobos K., Puciato D. (2013), Dekalog współczesnego zarządzania. Najnowsze nurty, koncepcje i metody, Warszawa, Difin.

Nogalski B., Wójcik-Karpacz A., Karpacz J. (2006), Uwarunkowania podatności małych przedsiębiorstw na zmiany, „Współczesne Zarządzanie”, nr 2, s. 34-46.

Raport (2015), Raport o stanie sektora małych i średnich przedsiębiorstw w Polsce w latach 2013-2014, Warszawa, Polska Agencja Rozwoju Przedsiębiorczości. 
Rozporządzenie Komisji (WE) $\mathrm{nr}$ 70/2001 z dnia 12 stycznia 2001 r. w sprawie zastosowania art. 87 i 88 Traktatu WE w odniesieniu do pomocy państwa dla małych i średnich przedsiębiorstw, Dziennik Urzędowy L 010, 13/01/2001 P. 0033-0042.

Safin K. (2012), Zarządzanie małym i średnim przedsiębiorstwem, Wrocław, Wydawnictwo Naukowe Uniwersytetu Ekonomicznego we Wrocławiu.

Skowronek-Mielczarek A. (2015), Uwarunkowania zmian zachowań małych i średnich przedsiębiorstw w warunkach kryzysu, ,Marketing i Rynek", nr 5, s. 46-59.

Szydło M. (2005), Swoboda działalności gospodarczej, Warszawa, C.H. Beck.

Szydło M. (2011), Wolność działalności gospodarczej jako prawo podstawowe, Wrocław-Bydgoszcz, Oficyna Wydawnicza Branta.

Targalski J. (2014), Przedsiębiorczość i zarządzanie małym i średnim przedsiębiorstwem, Warszawa, Difin.

Ustawa z dnia 2 lipca 2004 r. o swobodzie działalności gospodarczej, Dz. U. z 2015 r. poz. 584, ze zm.

\title{
Legal and Administrative Barriers to the Functioning of Small Businesses from the Opole Region
}

\begin{abstract}
This article aims to identify the main legal and administrative barriers which limit the functionality and development of micro-, small, and medium-size businesses. The study was based on three main research methods: document analysis, statistical method and diagnostic survey, which comprised in-depth interview. The study involved 58 owners or managers of small businesses from the Opole region. Results of this study confirmed the existence of barriers related to procedures, institutions, the judiciary, legal system, legal protection and public procurement. Earlier work related mainly to barriers of economic nature, but rarely analyzed legal and administrative barriers. The findings may be of interest to public authorities which should take measures to bridge the barriers reported by the surveyed entrepreneurs. Future research should include a larger group of companies from the entire Poland. As particularly important, it should also consider the issues of public procurement, which will be considered also in the subsequent work of the authors.
\end{abstract}

Keywords: institutional economics, entrepreneurship, small business, Opole region, barriers to development, regulatory environment.

\footnotetext{
Badania zostały sfinansowane ze środków Narodowego Centrum Nauki, w ramach grantu otrzymanego w Konkursie SONATA BIS pt.: „Nadzór publiczny nad rynkiem zamówień publicznych", którego kierownikiem jest prof. dr hab. Marek Szydło z Wydziału Prawa, Administracji i Ekonomii Uniwersytetu Wrocławskiego.
} 
